\title{
Digital Village in Implementing Village's Distance Learning Method
}

\author{
(Study Case: Duda Timur Village, Selat Sub-District, Karangasem District, Bali Province)
}

\author{
Varenna Faubiany* \\ Center of Research and Development \\ Ministry of Village, Development of Disadvantaged \\ Regions, and Transmigration \\ Jakarta, Indonesia \\ *vfhadie@gmail.com
}

\author{
Sosiati Gunawan \\ Center of Assessment and Learning \\ Ministry of Education and Culture \\ Jakarta, Indonesia \\ sosiati.gunawan@gmail.com
}

\begin{abstract}
Conducting distance learning is one kind of adjustment to teaching and learning system during pandemic covid-19. This research aims to describe distance learning problems, the efforts done by the Rural Government in supporting distance learning at Duda Timur Village, and to find out the solutions for the effectiveness of implementing distance learning methods in the village. This research uses qualitative research methods with case study by using data collecting method and indepth interview. Determining sample uses purposive sampling method. The target of this research includes the village head, village apparatus, and village community in Duda Timur Village. The success of Duda Timur village in achieving the title of Digital Village has a positive impact on the implementation of the PJJ program for TK / MI to SMA / MA / SMK students. Village officials are actively involved in socializing the community so that the PJJ program is easily implemented by the community. Support for facilities and infrastructure was also provided by the village head and his staff.
\end{abstract}

Keywords-digital village, distance learning, Duda Timur Village

\section{INTRODUCTION}

The Covid-19 pandemic has brought several changes in every aspects of people's life, including the village community. It is not only in the health sector but also in the education sector, people are required to implement a Clean and Healthy Lifestyle (PHBS) by means of 3M (Using Masks, Hand washing with soap for at least 20 seconds, and Keeping a distance). Education starting from the early childhood education level to tertiary education is all done using the Distance Learning (PJJ) method. As in previous research mentions that Covid-19 pandemic rules such as avoiding crowds and social distancing should make a rapid change in learning methods [1]

This Distance Learning Method is actually not a new method in the education system. This Distance Learning Method was first applied in the United States since 1982 when the University of Chicago launched the first distance learning program for Higher Education level. This Distance Learning Method is increasingly developing along with the development of various kinds of communication and information technology. In 1996, John Bourne developing Asychronous Learning Network Web which can provide education anytime and anywhere via the internet.

The role of the Ministry of Village, Development of Disadvantaged Regions, and Transmigration based on Law No 6 of 2014 on Villages [2] implemented a program namely Digital Village and Smart Village that can changing the attitude of the society be more enthusiastic. Digital village is a concept of village development by utilizing digital technology, both in public services and regional development.

This study is relevant to the current conditions affected by Covid-19 pandemic. Digital technology is able to keep students joining the class without leaving it during pandemic season. Students still can get practical knowledge without leaving home. Digital technology can be learning media to support village distance method during the pandemic.

There is no gap that we found in this program. The role of village heads who are proactive, open to changes or new information, being able to establish active communication with the community, are important factors in running this PJJ program.

Based on data from the Directorate General of Teachers and Education Personnel, Ministry of Education and Culture [3], it reported that more than $91 \%$ of the world's student population was affected by the Covid-19 pandemic so that schools were closed. This pandemic causes countries to ensure that the National Education System continues and all students have equal access to quality education.

The Circular of the Minister of Education and Culture Number 4 of 2020 [4] concerning the Implementation of Education Policies in the Emergency of the Spread of the Covid19 Virus states that the Teaching and Learning Process is carried out from Home with the Distance Learning Method. This Distance Learning method is expected to provide a meaningful learning experience for students without being burdened by the demands of completing all the achievements of the curriculum 
for class promotion and graduation; focuses on life skills education, among others regarding the Covid-19 pandemic; provide a variety of activities and learning assignments from home among students, according to their respective interests and conditions, including considering gaps in access / learning facilities from home; and provide feedback on evidence or products of qualitative and useful home learning activities.

The role of the teacher is still important in this Distance Learning Method where the teacher must continue to help students deal with the uncertainty caused by the pandemic and involve students to continue learning even though normal school activities are disrupted. The principles to be applied in this Distance Learning Method are:

- Harmless as teachers all over the world try to reduce the possible disadvantages of learning due to school disruptions, student safety and well-being should be the most important things to think about, efforts to deliver the curriculum so far do not create more stress and anxiety for students and their families;

- Realistically, teachers are expected to have realistic expectations about what can be achieved by distance learning, and use professional judgment to assess the consequences of the learning plan.

The three main tasks in designing and implementing Distance Learning are: the content / content of the material to be taught and delivered must keep following the changes in curriculum, policies, or existing guidelines; student learning profiles, conditions, and needs; and how to build personal and professional strengths as teachers in facing all kinds of challenges that will be faced and what solutions can be given to overcome all the problems and challenges that exist.

In addition, internet access has become an important requirement in supporting the Distance Learning Method. Not only related to the availability of devices, but also the availability of internet quotas and the strength of the internet signal have an effect on the smoothness of the teaching and learning process.

Desa Digital is a program focusing on the process of digitization, information disclosure, and the use of technology and information facilities in empowering village communities and developing village potential. The Village Government creates a village website that contains village information, integrated basic services for the community such as managing letters, cards, and so on. Apart from that, the Village Government is also obliged to conduct socialization and provide teaching on the use of the internet to the Village community.

During this pandemic, internet access is needed to support Distance Learning Methods. Therefore, the presence of Digital Village is expected to contribute to society regarding the provision of internet facilities. This research was conducted to see what efforts have been made by the Village Government, including the Digital Village, in supporting the teaching and learning process using the Distance Learning method. In previous research mentioned that virtual technology-based media is able to be more suitable for new millenial generation, it might be more productive [3].

\section{RESEARCH METHODS}

This research was conducted in Duda Timur Village, Selat District, Karangasem Regency, Bali Province. This research was conducted from October to November 2020

The data used in this study consisted of primary data and secondary data. Primary data were obtained through questionnaires and online interviews with the Village Head of Duda Timur Village. This study used a purposive sampling technique by taking 30 respondents.

Indepth interview is the method for gathering data from respondents. The respondents are the Village Head, village apparatus, parents, and high school students, intermediate, and elementary. The other which is relate to the type of work can be specified as KPM Cadre, BKB Cadre, Regional Head, Student, Village Officer, Village Secretary, Village Office Staff, Entrepreneur, and Nurse. The interview duration is about 20 to 25 minutes per respondent. The interviewers using questionnaire to gather data.

\section{FINDINGS AND DISCUSSION}

Based on the data from the questionnaire of the Village of Duda Timur on Distance Education, it can be specified that the number of respondents is 29 people, ranging in age from 15 to 57 years, most of the most recent education $(82.8 \%)$ are high school, $13.8 \%$ undergraduate, and $3.4 \%$ elementary school (SD). 1 person). The position or type of work of the respondent can be specified as KPM Cadre, BKB Cadre, Regional Head, Student, Village Officer, Village Secretary, Village Office Staff, Entrepreneur, and Nurse.

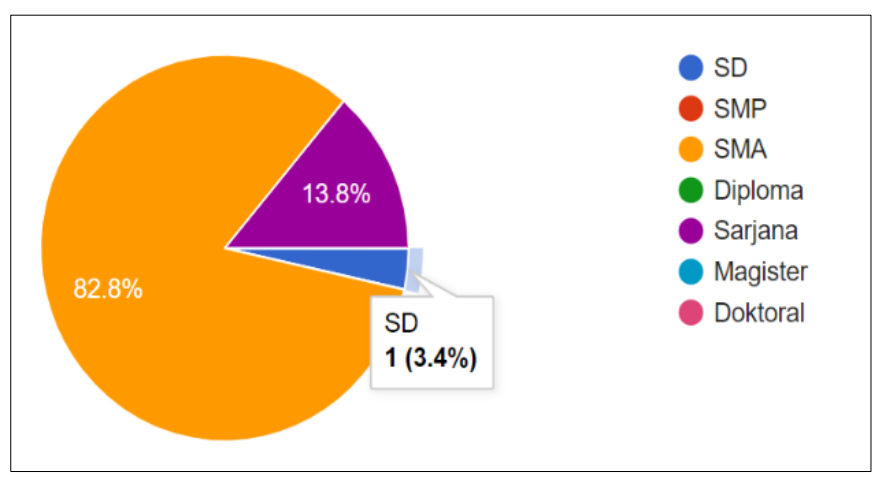

Fig. 1. Educational backgrounds of the respondents.

The following explanation is the response from each statement on the questionnaire:

More than half of the respondents $(51.72 \%)$ stated that the term Distance Learning (PJJ) program was easily understood by the community. 


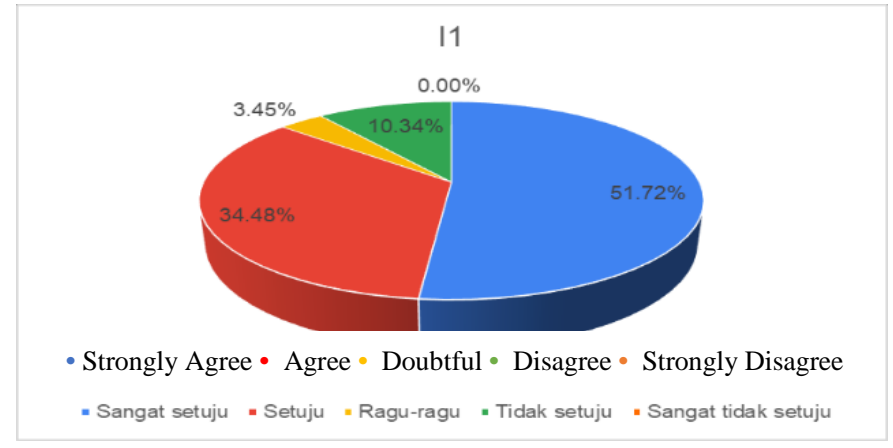

Fig. 2. Distance Learning Program was easily understood by the community

Almost half of respondents $(48.28 \%)$ stated that teachers or other education personnel easily understand the PJJ learning method.

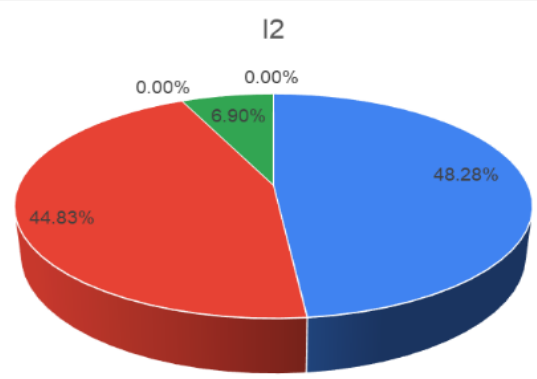

- Strongly Agree • Agree • Doubtful • Disagree • Strongly Disagree

Fig. 3. PJJ learning method is easily understood by teacher or other educational staff.

As many as $44.83 \%$ of the community stated that it was not easy to accept the PJJ program as a means of learning since the Covid-19 pandemic, $24.1 \%$ agreed with the program, and $31 \%$ of respondents agreed with the program, so it appears that there are variations in the responses given by respondents.

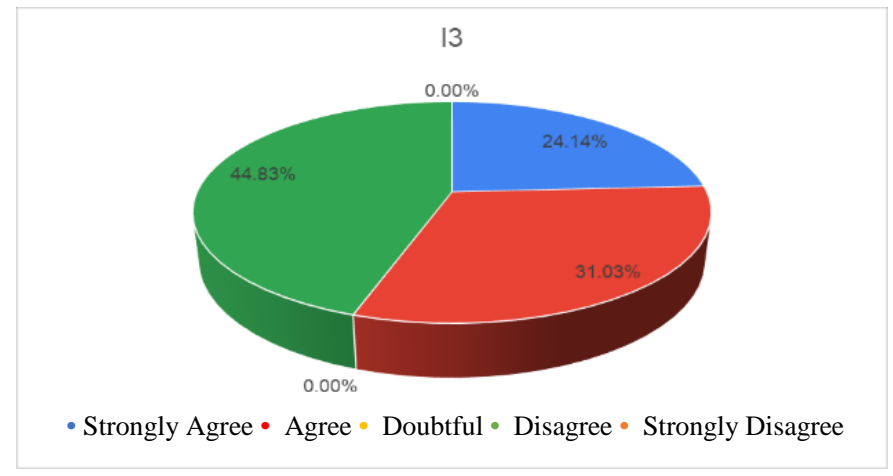

Fig. 4. Understanding level of PJJ program since Covid-19 pandemic.
Most (75.9\%) of respondents stated that PJJ is a product of the challenging advancement of communication and information technology. This is supported by the success of Duda Timur Village to become a Digital Village, so that people are familiar with the use of technology devices as information media.

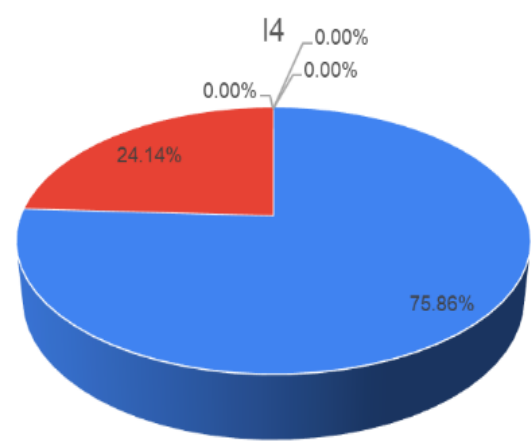

- Strongly Agree • Agree • Doubtful • Disagree • Strongly Disagree

Fig. 5. PJJ Program is advancing communication and information technology

Multimedia content will be richer and learning methods will no longer be limited by time and space. Most respondents (79.3\%) strongly agree that the learning methods are more varied and can be adapted to the material being studied.

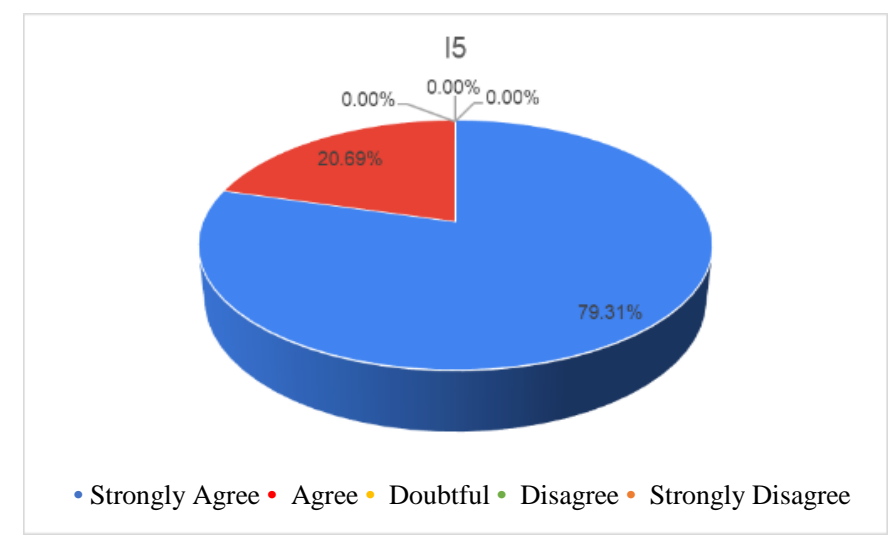

Fig. 6. Learning methods are more varied and more acceptable.

According to most respondents $(79.31 \%)$ PJJ is a breakthrough in the way of learning for students from kindergarten to high school levels. 


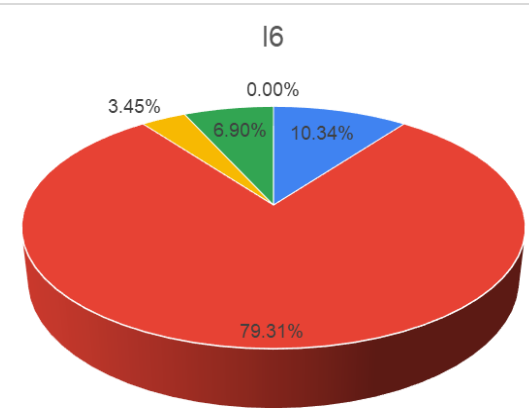

- Strongly Agree • Agree • Doubtful • Disagree • Strongly Disagree

Fig. 7. PJJ is a breakthrough in the way of learning methods.

The PJJ program has the effect that the role of teachers become more structured. This is stated by the majority of respondents $(86.21 \%)$.

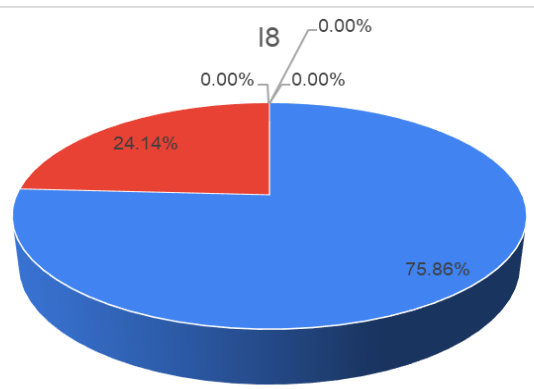

- Strongly Agree • Agree • Doubtful • Disagree • Strongly Disagree

Fig. 8. The role of teachers become more structured.

The potential strength of human resources of productive age, the education level of society, and openness to information are also important factors for the success of the PJJ program, strongly supported by the majority $(75.86 \%)$.

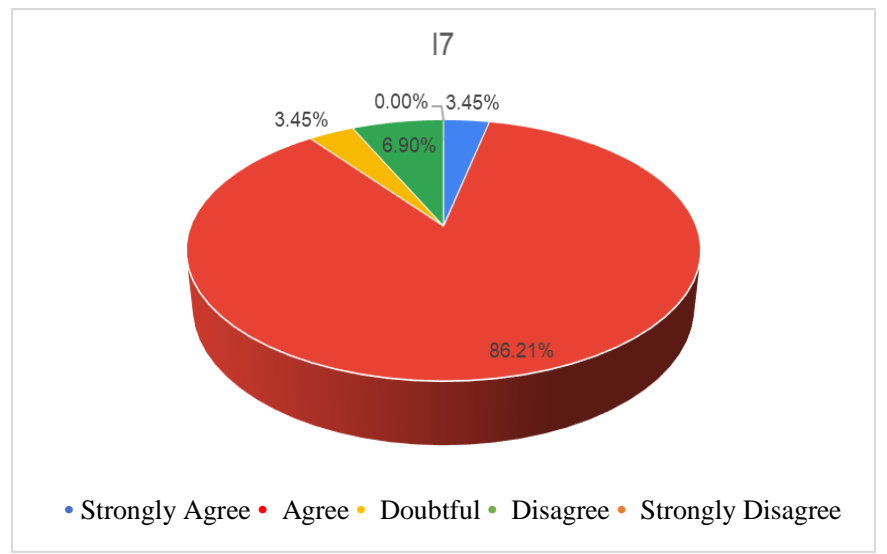

Fig. 9. The supporting factors for the success of the PJJ Program.
Respondents in Duda Timur Village stated that they strongly agreed $(75.89 \%)$ that having human resources from the millennial group who were familiar with the village's vision and mission, thus it greatly supported the PJJ program.

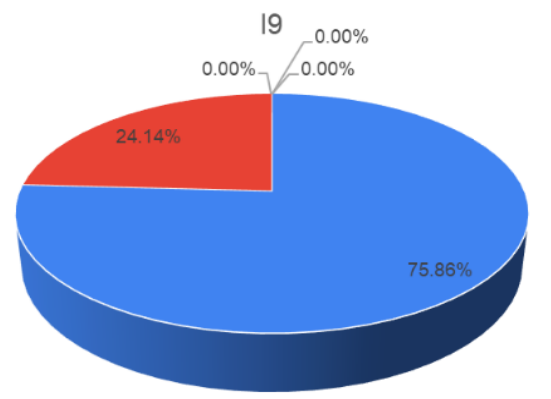

- Strongly Agree • Agree • Doubtful • Disagree • Strongly Disagree

Fig. 10. Millenial group is greatly supported the PJJ program.

As many as $75.86 \%$ of respondents stated that the success of the PJJ Program could be implemented quickly because Duda Timur Village is a Digital Village

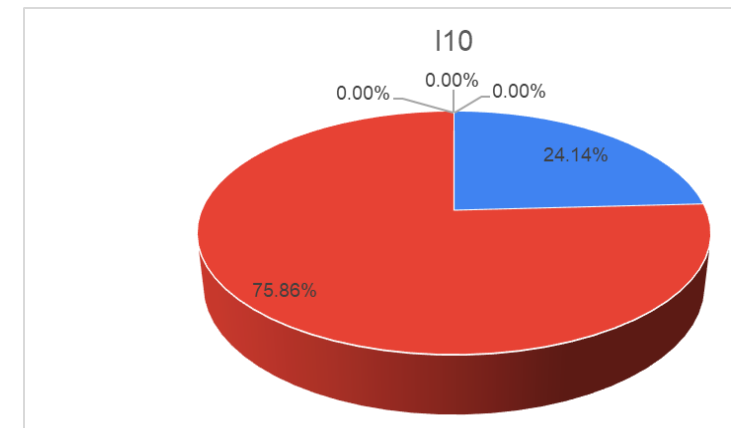

- Strongly Agree • Agree • Doubtful • Disagree • Strongly Disagree

Fig. 11. PJJ program is quickly implemented in digital village.

Respondents strongly agree with the information that Digital Village is one of the realizations of the "dream" of becoming a village that is advanced, technology literate, especially for adolescents and youths in Duda Timur Village (82.76\%). So it can be said that this is an important factor for the success of the PJJ program, especially for students from kindergarten to high school levels. 


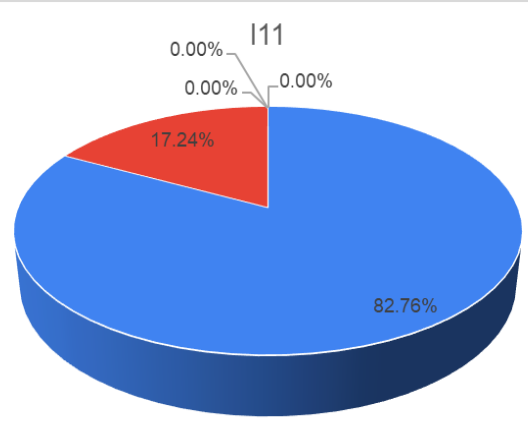

- Strongly Agree • Agree • Doubtful • Disagree • Strongly Disagree

Fig. 12. PJJ program is one of the dreams of a digital village.

The people of Duda Timur Village easily accept the PJJ program through intensive socialization from the Village Head, $75.86 \%$ of respondents agree. This is one of the commitments of the village head to always provide fast information to the community, supported by adequate infrastructure.

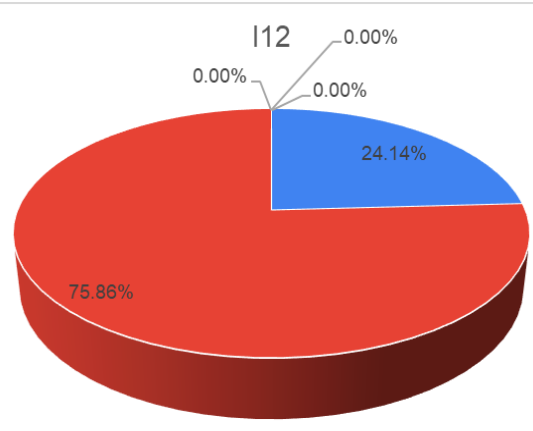

- Strongly Agree • Agree • Doubtful • Disagree • Strongly Disagree

Fig. 13. Intensive socialization is one of the key to the success of PJJ Program

Respondents agreed $(75.86 \%)$ that the PJJ program in Duda Timur Village supports the Government's program to improve human and village resources so that they develop into a Digital Village.

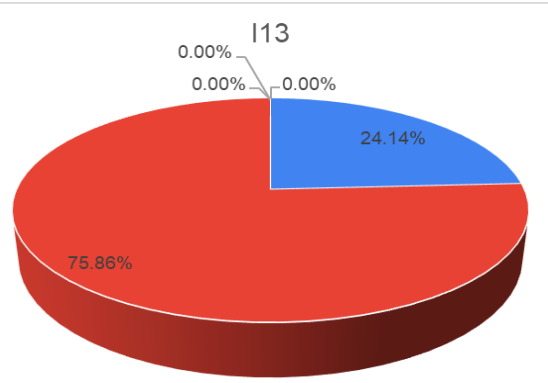

- Strongly Agree • Agree • Doubtful • Disagree - Strongly Disagree

Fig. 14. PJJ Program is supporting Digital Village program.
Apart from being a learning medium, the PJJ program can also be a means of promoting cultural arts (for example the Sang Hyang Jarang dance) through current technology and educational facilities. This is supported by respondents as much as $68.97 \%$ stated that they strongly agree that PJJ has a positive impact on other aspects of society.

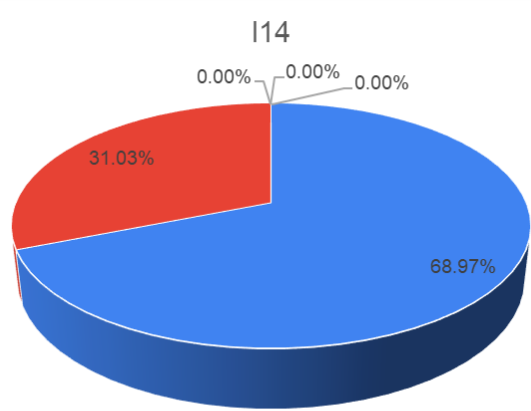

- Strongly Agree • Agree • Doubtful • Disagree • Strongly Disagree

Fig. 15. PJJ program can also promoting cultural arts.

Respondents strongly agree $(75.86 \%)$ that the existence of good cooperation between village officials and the community, especially parents of students, is one of the keys to the successful implementation of the PJJ program.

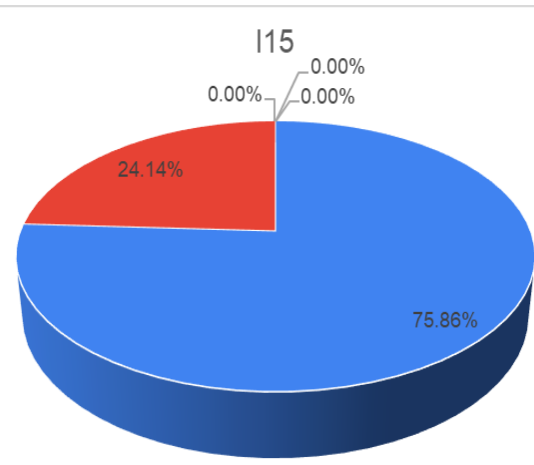

- Strongly Agree • Agree • Doubtful • Disagree • Strongly Disagree

Fig. 16. Good cooperation between village officials and community is one of the key to the success of PJJ program.

Respondents agreed $(79.31 \%)$ that the PJJ program in Duda Timur Village was based on instructions from the Governor regarding the development of the Village as a State asset. Apart from that, the success of being a Digital Village, and other achievements made by Duda Timur Village should be appreciated. 


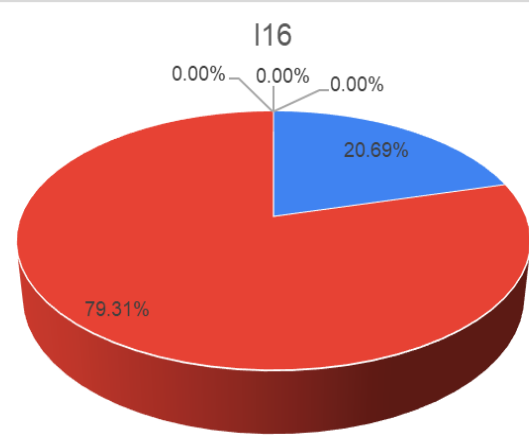

- Strongly Agree • Agree • Doubtful • Disagree • Strongly Disagree

Fig. 17. PJJ Program was based on Governor's instructions.

The community in Duda Timur Village is very open and supports the PJJ program because they have felt the positive benefits of the Digital Village program $(75.86 \%)$. This is reinforced by the statement of the village head that every village program is known to the community and the village head's office is open to the community.

\section{7}

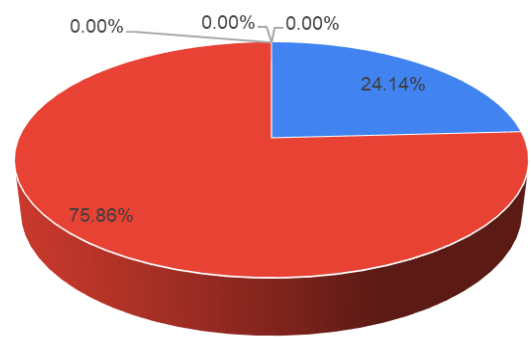

- Strongly Agree • Agree - Doubtful - Disagree - Strongly Disagree

Fig. 18. PJJ program brings positive benefits of the Digital Village program.

A total of $72.41 \%$ of respondents strongly agree that every program that will be launched by the Village Head for the community in Duda Timur Village will be held in scheduled discussions and attended by Village officials from each Banjar

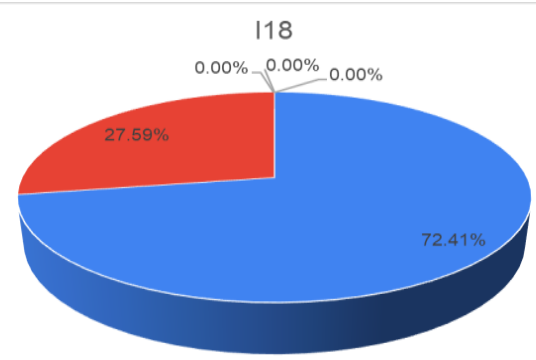

- Strongly Agree • Agree • Doubtful • Disagree • Strongly Disagree

Fig. 19. There always internal meeting for coordination before running program
Good communication by village officials to the general public, youth, and students in Duda Timur Village is the strength for the success of every program that is run. Even the village head and his staff provide freedom of time to communicate. This means that the leadership pattern that is applied can make people feel comfort Fig. and willing to work together. (86.21\%)

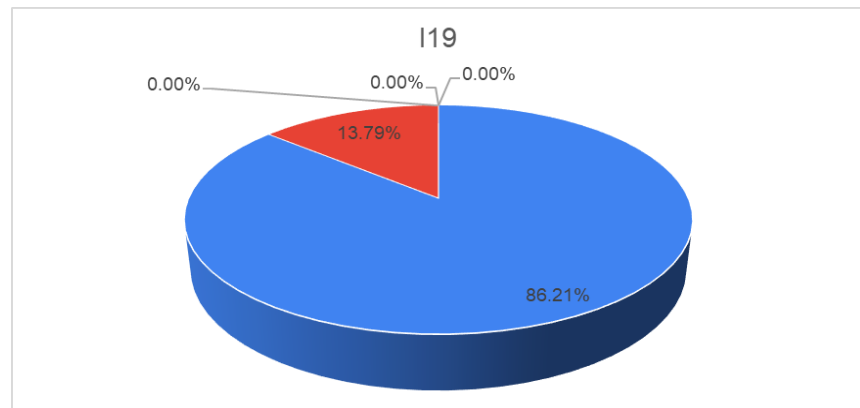

- Strongly Agree • Agree • Doubtful • Disagree • Strongly Disagree

Fig. 20. Good leadership make people feel comfort.

Respondents acknowledged that the PJJ program had an impact on various lines of community life in Duda Timur Village, not only as a learning method for kindergarten to high school students. However, it also has an impact on the types of activities that are developed both by teenagers, PKK mothers, with the support of their village heads. Respondents stated that they strongly agreed with the statement, $65.52 \%$.

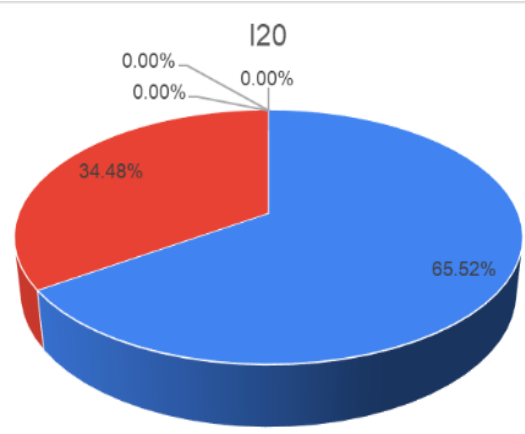

- Strongly Agree • Agree • Doubtful • Disagree • Strongly Disagree

Fig. 21. PJJ program had an impact on various lines of community life.

Based on information on the success rate of developing into a Digital Village, the important thing is guidance and guidance from the Ministry of Villages, Development of Disadvantaged Areas, and Transmigration (Kemendesa PDTT) to be one of the benchmarks for success in becoming a Digital Village so that the PJJ program shows direct benefits in the community. This was stated by $65.52 \%$ of respondents. 


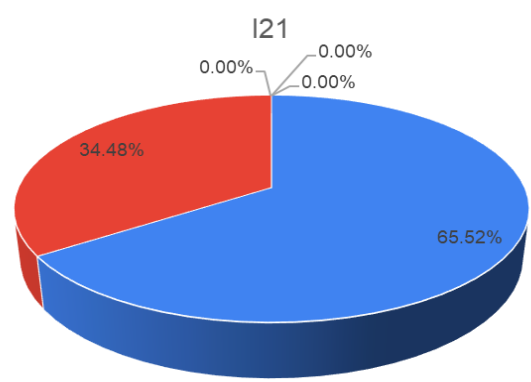

- Strongly Agree • Agree • Doubtful • Disagree • Strongly Disagree

Fig. 22. Clear guidance are important for benchmark of PJJ program.

Equally important is the role of mothers who are members of social groups (e.g BKB, Posyandu, etc.), as much as $82.76 \%$ expressed their support and contributed to providing ideas for the development of PJJ program content.

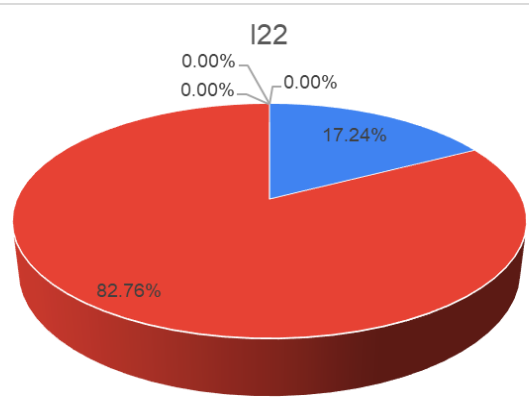

- Strongly Agree • Agree • Doubtful • Disagree • Strongly Disagree

Fig. 23. The role of mothers who are social groups members in PJJ program.

The PJJ program has a positive effect on people's attitudes towards education in Duda Timur Village (68.97\%)

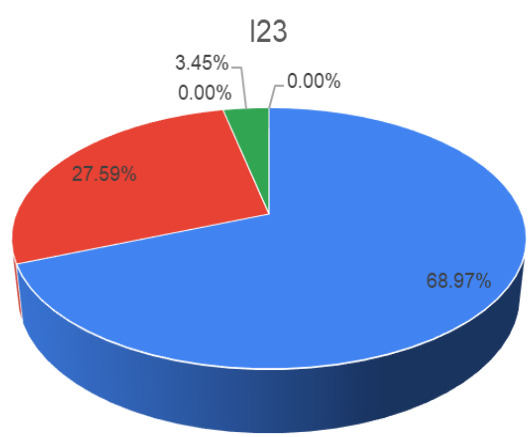

- Strongly Agree • Agree • Doubtful • Disagree • Strongly Disagree

Fig. 24. PJJ program has a possitive effect on people's attitudes towards education.
The involvement of youths / girls (65.52\%) who are members of the Karang Taruna organization shows their concern for the programs in each Banjar of Duda Timur Village so that they act as agents of change in the learning system to PJJ program.

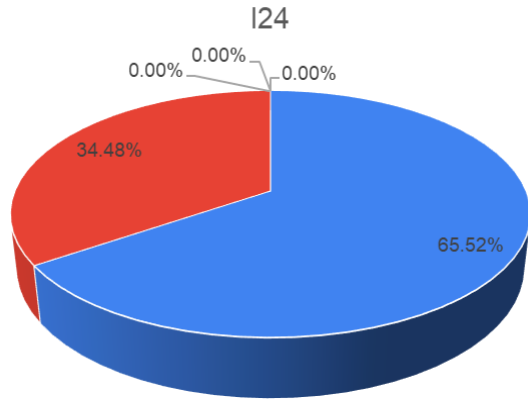

- Strongly Agree • Agree • Doubtful • Disagree • Strongly Disagree

Fig. 25. Youth generations as village's agent of change.

Respondents agree $(65.52 \%)$ that increasing electric power and internet signal strength so that people in need can easily access them, can be facilitated by the Duda Timur Village Fund

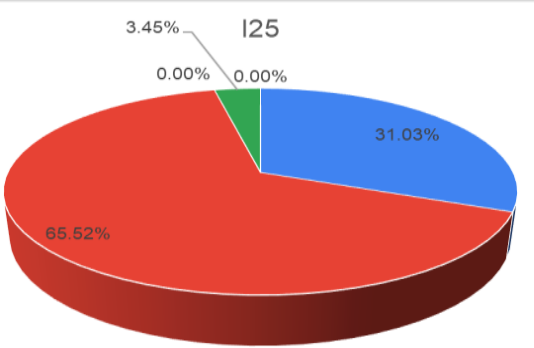

- Strongly Agree • Agree • Doubtful • Disagree • Strongly Disagree

Fig. 26. Facilitating the need of PJJ program by the village fund.

Respondents strongly agree $(68.97 \%)$ that the intensity of socializing the PJJ program from the village head is one of the strengths of the successful implementation of the program.

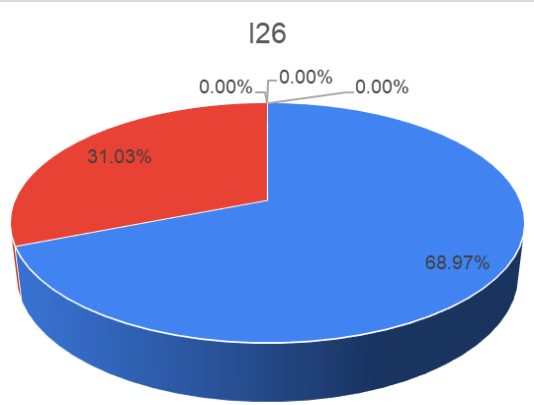

- Strongly Agree • Agree • Doubtful • Disagree • Strongly Disagree

Fig. 27. The intensity of socializing the PJJ program is important.

As many as $72.41 \%$ of respondents stated that they strongly agreed with the leadership pattern and information disclosure 
from the village's head and this was responded positively by the community.

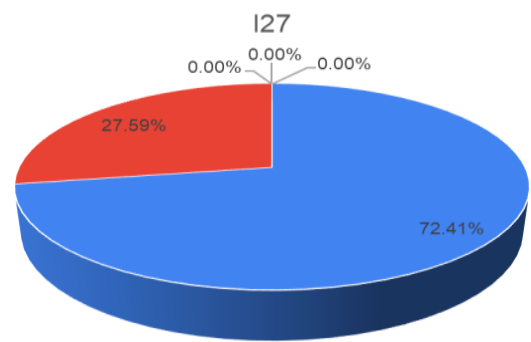

- Strongly Agree • Agree • Doubtful • Disagree • Strongly Disagree

Fig. 28. The Village's Head Leadership was responded positively by the community.

As many as $72.41 \%$ of respondents strongly agreed that the PJJ program was implemented since the Covid-19 pandemic, applied to school-age students.

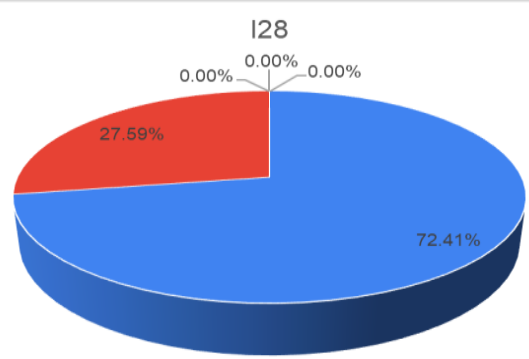

- Strongly Agree • Agree • Doubtful • Disagree • Strongly Disagree

Fig. 29. PJJ program was implemented since the Covid-19 pandemic

$82.76 \%$ of respondents agree that internet access for PJJ for the community is easier.

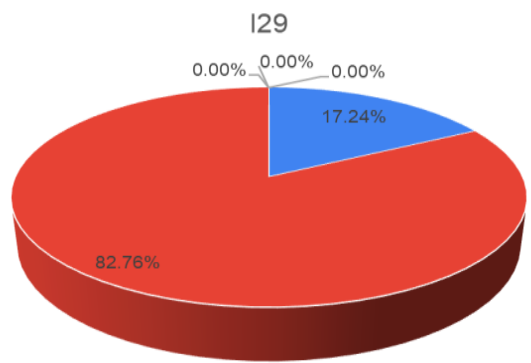

- Strongly Agree • Agree • Doubtful • Disagree • Strongly Disagree

Fig. 30. Internet access made PJJ program is easily implemented

The PJJ program in Duda Timur Village can be implemented directly because it already has adequate facilities and infrastructure. This was stated by the majority of respondents $(62.07 \%)$.

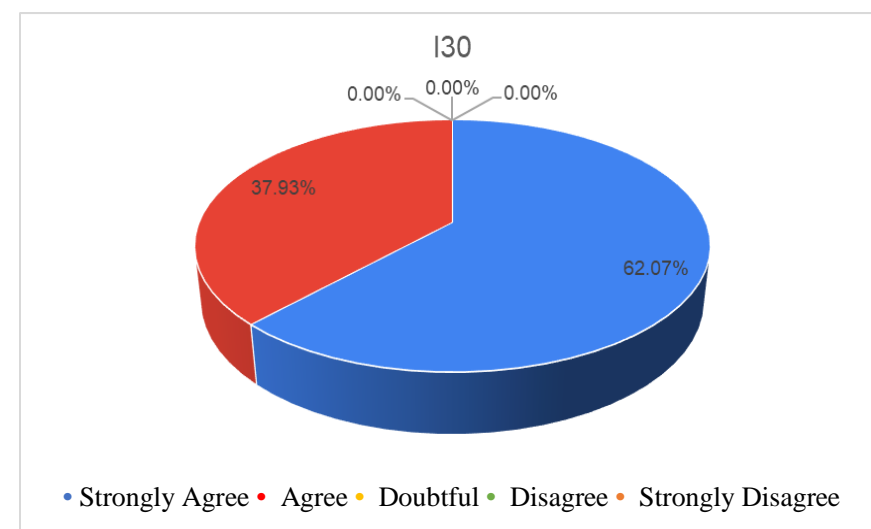

Fig. 31. Adequate facilities and infrastructure supporting PJJ program.

Respondents agree $(79.31 \%)$ that the additional power and the provision of free $\mathrm{Wi}-\mathrm{Fi}$ access in public facilities are derived from the policies of the village head.

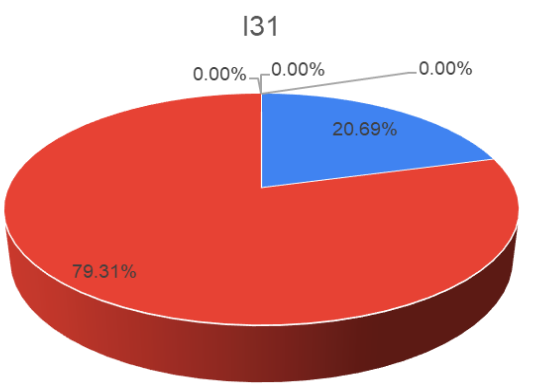

- Strongly Agree • Agree • Doubtful • Disagree - Strongly Disagree

Fig. 32. The needs of additional power and the provision of free wifi.

The rate of school-age dropouts decreased after the PJJ program was established across Banjar (65.52\%).

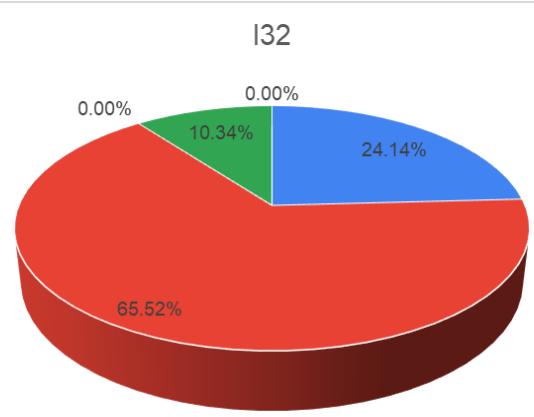

- Strongly Agree • Agree - Doubtful • Disagree - Strongly Disagree

Fig. 33. PJJ program decreased the number of school-age dropped outs. 
Village heads are responsive to pandemics and provide facilities that support the PJJ program. This was stated by $65.52 \%$ of respondents.

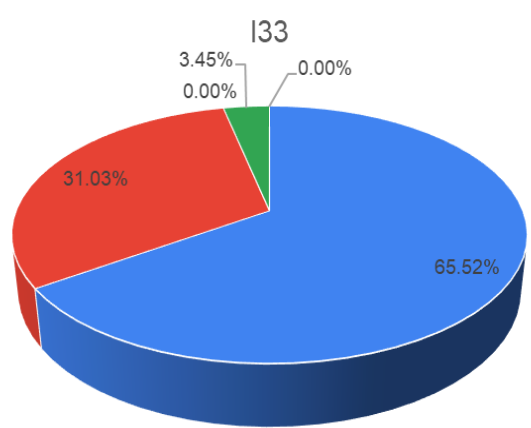

- Strongly Agree • Agree • Doubtful • Disagree • Strongly Disagree

Fig. 34. Responsibility of Village Head during this pandemic.

Apart from the information above, the respondents were given the opportunity to also provide information regarding any obstacles during the implementation of PJJ during this pandemic. There are several inhibitory factors in implementing distance learning method in Duda Timur Village, namely:

1) the signal strength lacks support and data packages tend to be a lot of extra expenses, the telecom network is not yet available or too slow. Sholihin [5] stated that this pandemic brings us to online teaching methods which is requires strong signal and internet support.

2) The perceived obstacle is difficulty accepting and understanding the learning material provided by the teacher. Sometimes some parents have difficulty understanding the learning materials before explaining to their child. This causes parents to be uncomfortable in accompanying their children during online learning. For example, when the students received materials through Google Classroom, they only filled the attendance and do not read or understood the materials shared by the teachers. Even worse the students did not attend and do not download existing materials through Google Classroom.

3) Some people do not have gadget that support for online learning. Some students do not have a communication medium in the form of a device which is the main requirement in the PJJ program due to the difficulties of their parent's economic conditions. Fortunately, Ministry of Education and Culture provides learning quota assistance so that those who live in remote areas are able to join the online learning class.

4) Some people are less familiar with the applications that support distance learning methods. Almost people unfamiliar with the implementation of distance learning methods. Intensive socialization must give by the teacher before run the distance learning method. In this pandemic season, it also important to have any kind of information about how to do distance learning method or online learning.

5) Parental abilities in assisting and completion their children's school tasks. Busy parents with their own affairs make it difficult to assisting and complete the school tasks during distance learning method. Role of parents is very important because they replace the role of existing teachers at school.

Distance learning method needs good cooperation between students, teachers, and their parents. In the implementation of distance learning method parents have more opportunities to interact directly with their children. Parents have a role as a teacher at home, teachers have a role as a parent at school. They are equally necessary in the learning process.

In addition to inhibitory factors, the supporting factors of distance learning method are:

1) the Village Head provides free wi-fi in public area which is easily accessible for the villagers. In order to fulfil the needs of the students to access education during this pandemic. Then the villagers who lived in remote area do not need to climb the hills to get internet signals. Government assistance to facilitate the development of Telkom's wi-fi throughout Duda Timur village areas. Moreover, affordable internet packages price, free wi-fi in public area, and affordable home internet installation can also help the community to overcome the problem of quota or internet signals.

2) Teacher's role to prepare the learning materials. It takes teacher's creativity in delivering learning materials to keep students excited about learning despite online learning. The slides should be made as interesting as possible. Distance learning method requires a high level of concentration and is easily bored so it is important to keep the mood of both teachers and students during learning process.

3) The teachers give a socialization about how to carrying out distance learning method to all parents and students. The teachers explain about the direction how to use distance learning applications such as Google Classroom, Google Meet, Zoom Meeting, etc. Luckily Duda Timur Village has an application SM@RT Desa which is very useful to provide any kind of informations during this pandemic.

4) Government assistance ensure that all the villagers belong to school ages or compulsory learning can participate in distance learning with smoothly and there are no distractions. it is so important to convince that all students do not have constraints of internet access and learning facilities. To simplify the needs of suitable gadget to endorse distance learning method, Village governance provide convenience to gives credit for the purchase of gadgets such as android phones, laptops, and internet installations. 


\section{CONCLUSION AND RECOMMENDATION}

\section{A. Conclusion}

The role of Village Head who are proactive, open to changes or new information, being able to establish active communication with the community, are important factors in running this PJJ program. On the other hand, he built a good relationship with vendors in developing Telkom's Wi-fi network almost all areas in the village. The communication with government agent has a positive role.

\section{B. Recommendation}

Empowering community groups such as youth youth groups in each Banjar as agents of change. If it is necessary, they will be given an opportunity to take part in useful training for community organizations.

\section{ACKNOWLEDGMENT}

The Authors would also like to thank all the people of Duda Timur Village who took part in the research, Mrs. Hayatun
Nufus for checking the language of the manuscript, and Mr. Mohammad Arif for helping in this research. The authors are grateful for the support of Center for Assessment and Learning for conducting the international seminar.

\section{REFERENCES}

[1] V. Ratten and P. Jones, The International Journal of Management Education, https://doi.org/10.1016/j.ijme.2020.100432

[2] Republik Indonesia. 2014. Undang-Undang Nomor 6 tahun 2014 tentang Desa.

[3] Kementerian Pendidikan dan Kebudayaan. Direktorat Jenderal Guru dan Tenaga Kependidikan. 2020. Panduan Pembelajaran Jarak Jauh Bagi Guru Selama Sekolah Tutup dan Pandemi Covid-19 dengan Semangat Merdeka Belajar.

[4] Republik Indonesia. 2020. Surat Edaran Menteri Pendidikan dan Kebudayaan Nomor 4 Tahun 2020.

[5] M. Sholihin, R. C. Sari, N. Yuniarti, S. Ilyana, "A new way of teaching business ethics: The evaluation of virtual reality-based learning media", The International Journal of Management Education, Volume 18, Issue 3, 2020, https://doi.org/10.1016/j.ijme.2020.100428. 